\title{
SECCIÓN FOTOGRÁFICA
}


CITAM Derechos Reservados.

La reproducción total o parcial de este artículo se podrá hacer si el ITAM otorga la autorización previamente por escrito. 


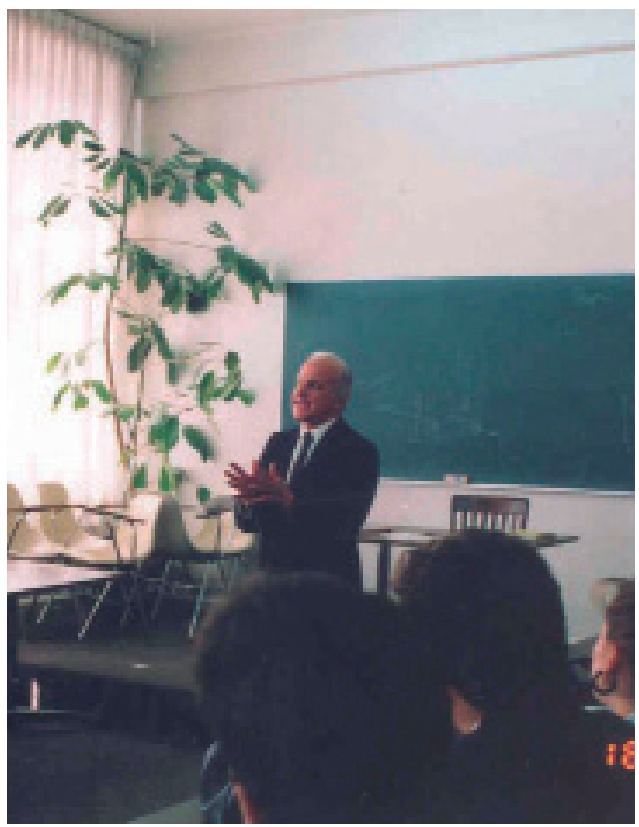

Carlos de la Isla en el salón de clase (1991).

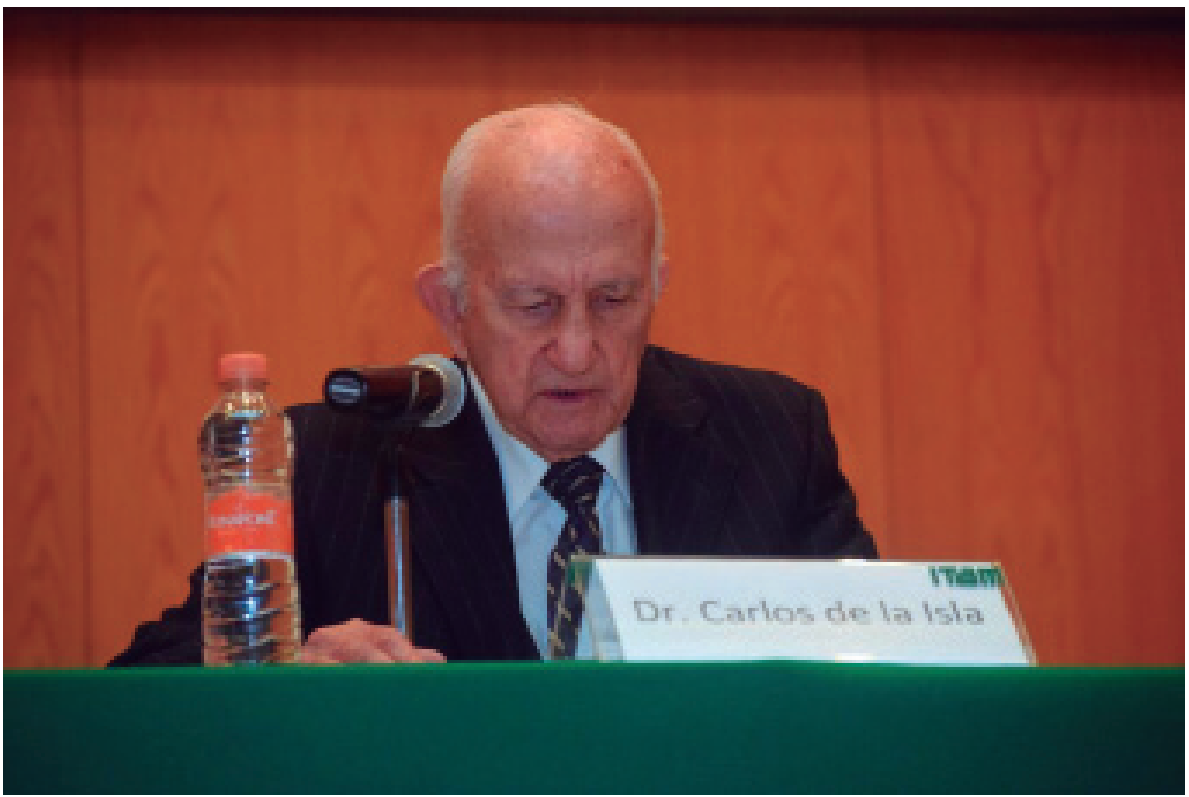

En una de sus incontables conferencias en el ITAM. 


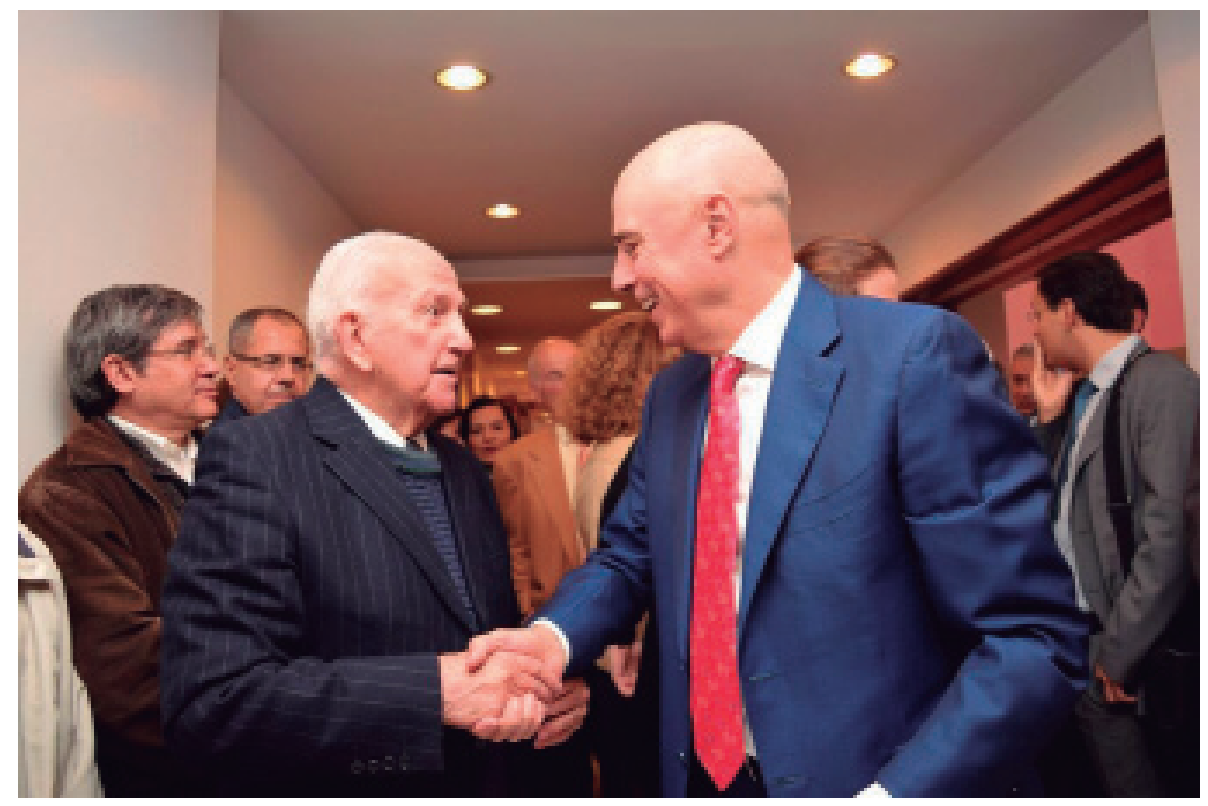

Con el rector Arturo Fernández, en la instauración del aula "Carlos de la Isla Veraza" (2016).

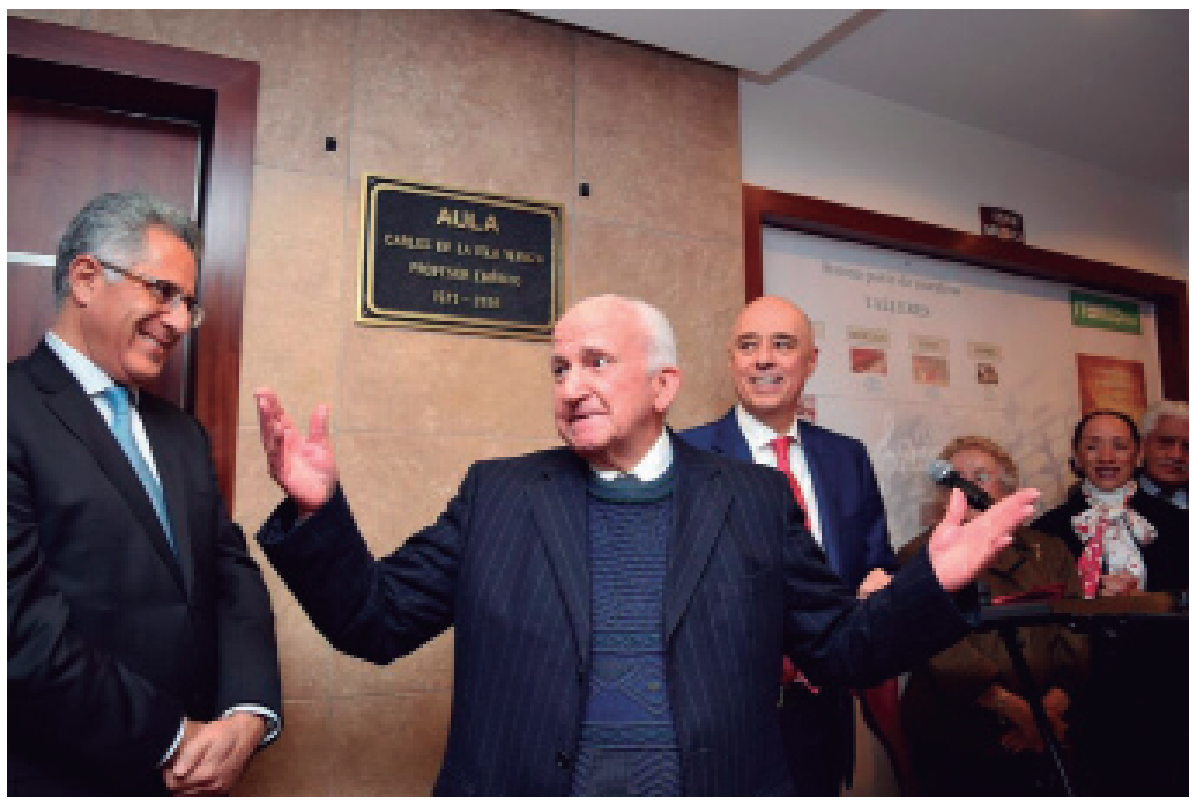

Con el rector Arturo Fernández y el vicerrector Alejandro Hernández, en la instauración del aula que lleva su nombre (2016). 


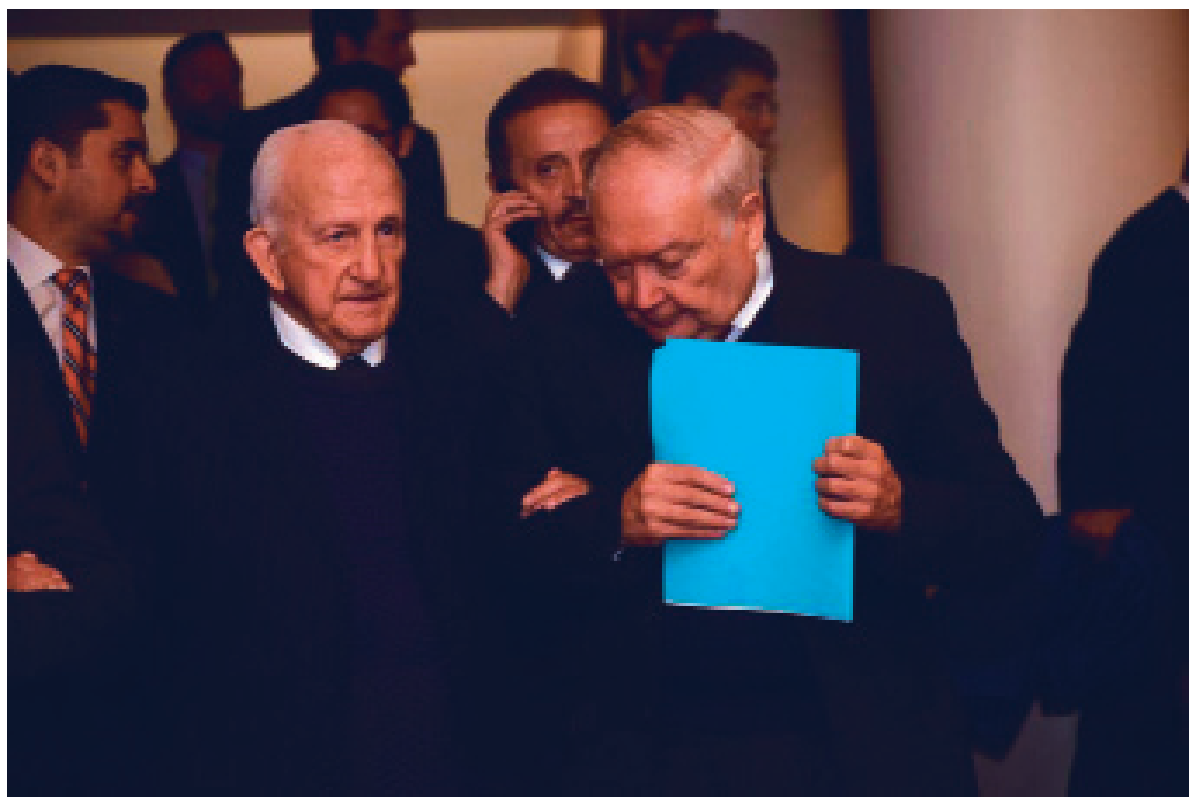

Con José Ramón Benito, director de la División Académica de Estudios Generales y Estudios Internacionales, en la instauración del aula (2016).

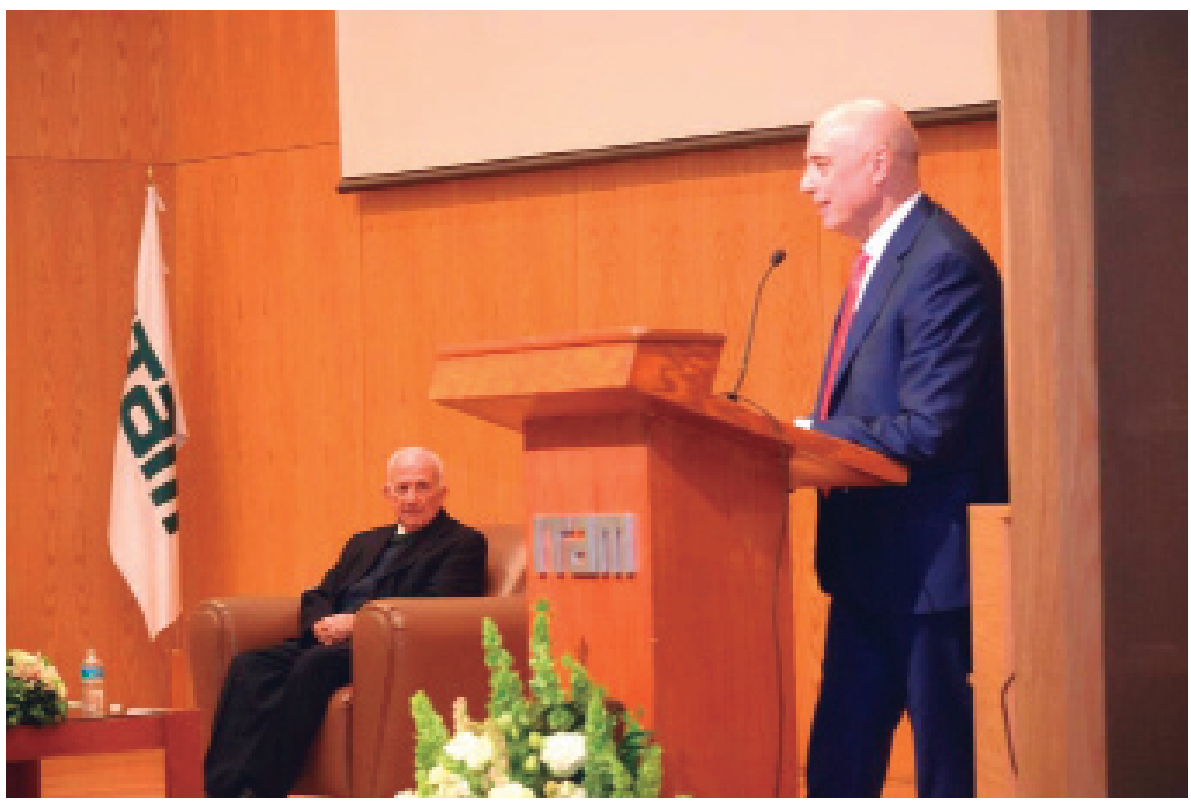

El rector Arturo Fernández, en el homenaje a Carlos de la Isla en el Auditorio Raúl Baillères (2016). 


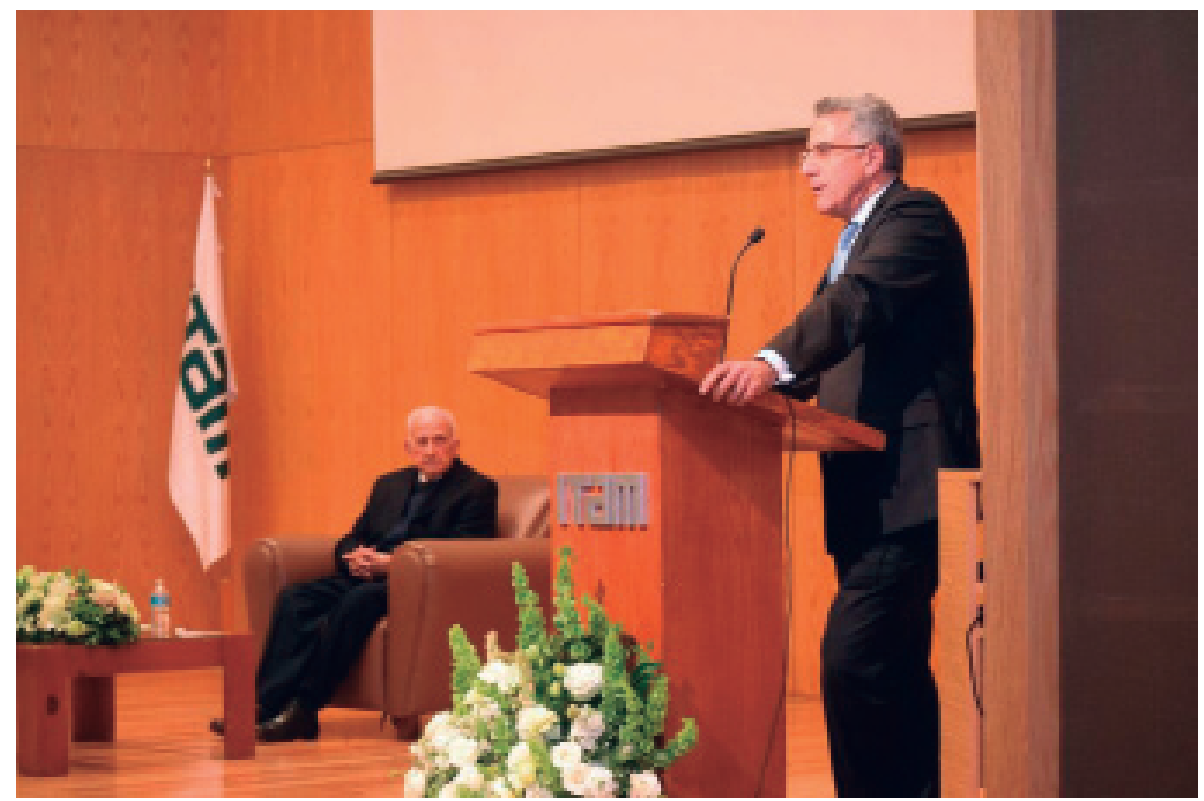

El vicerrector Alejandro Hernández, en el homenaje a Carlos de la Isla.

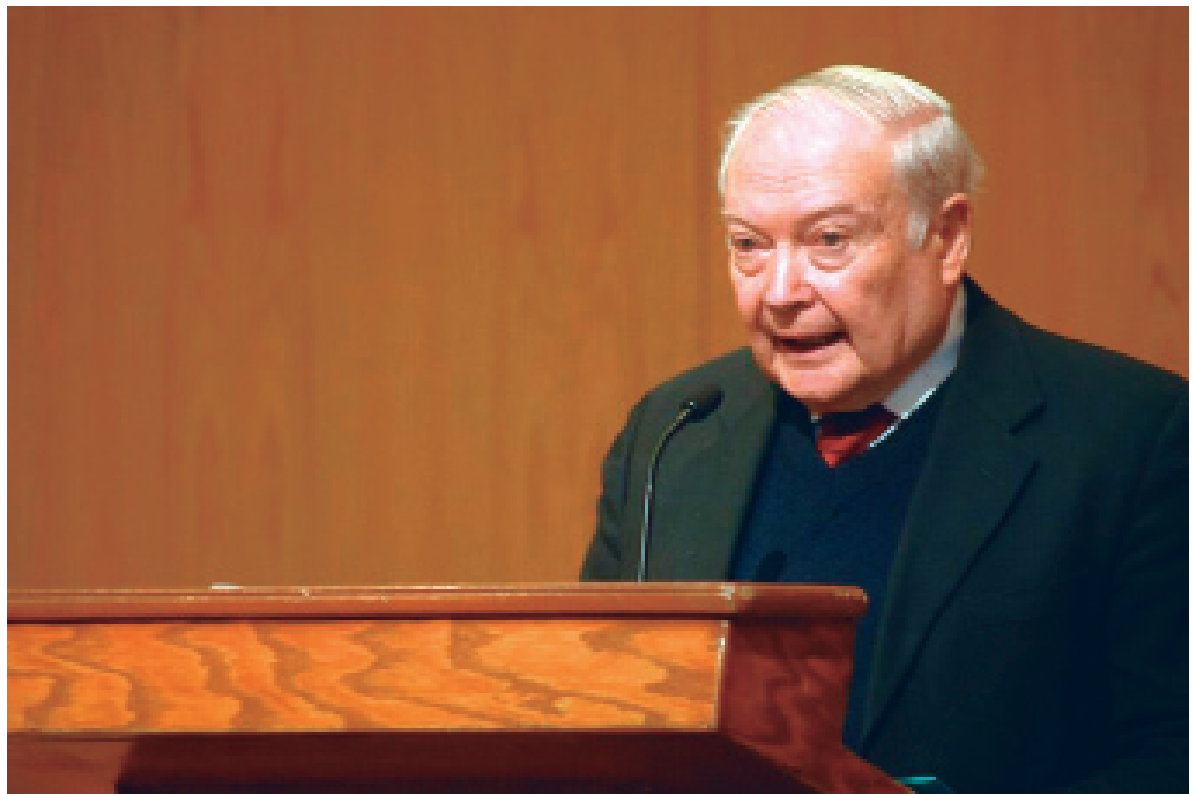

José Ramón Benito dirige unas palabras a Carlos de la Isla. 


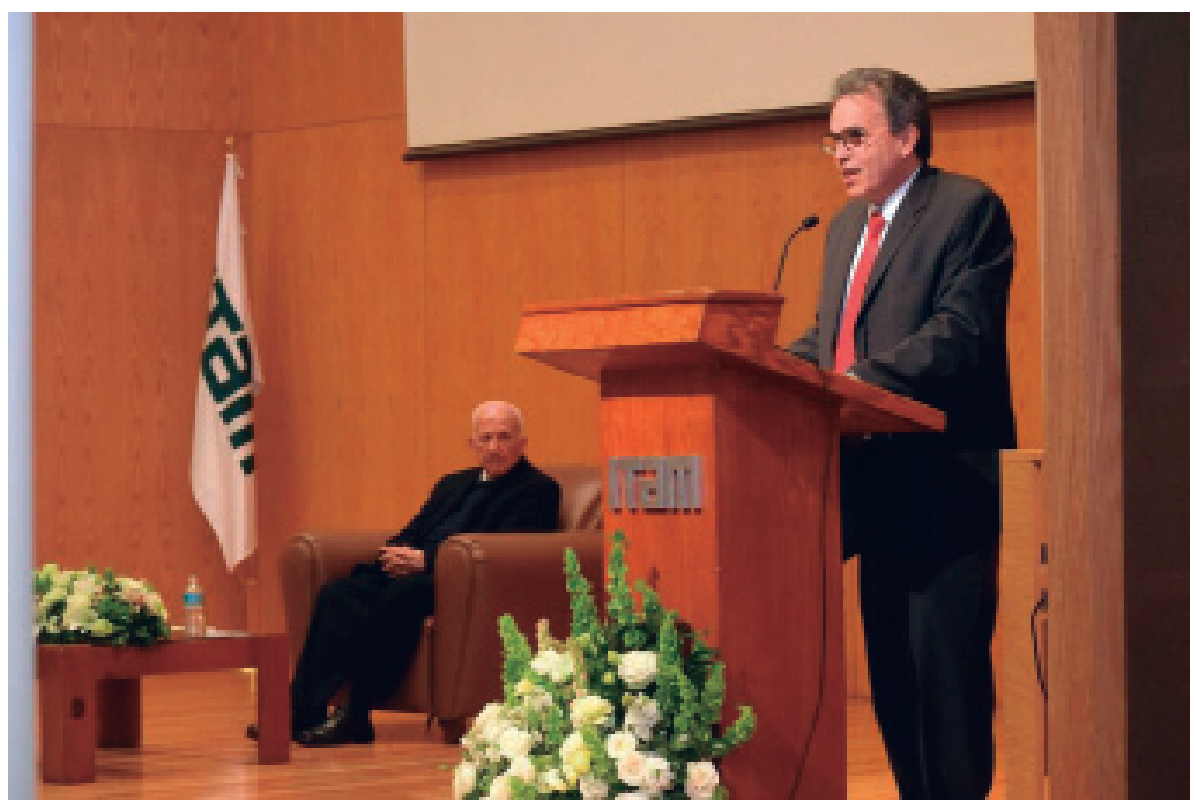

Carlos McCadden, jefe del Departamento Académico de Estudios Generales.

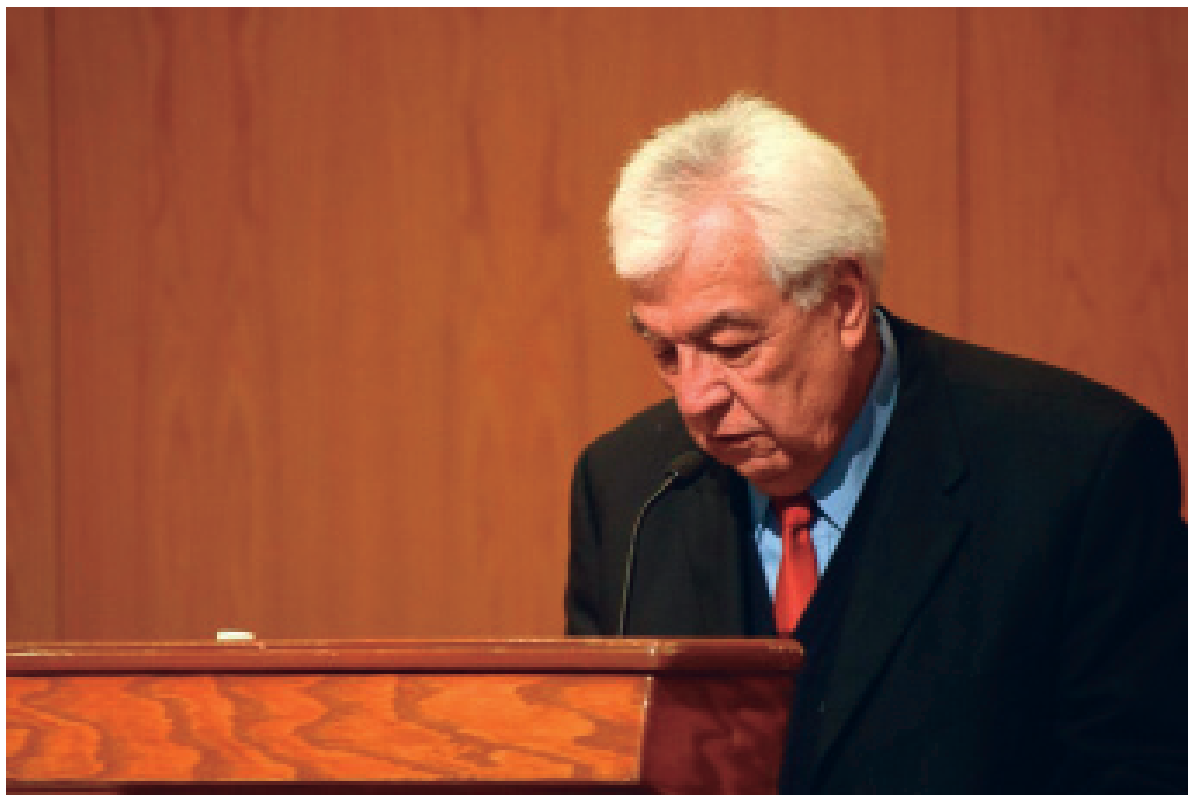

Patricio Sepúlveda en su discurso laudatorio de Carlos de la Isla. 


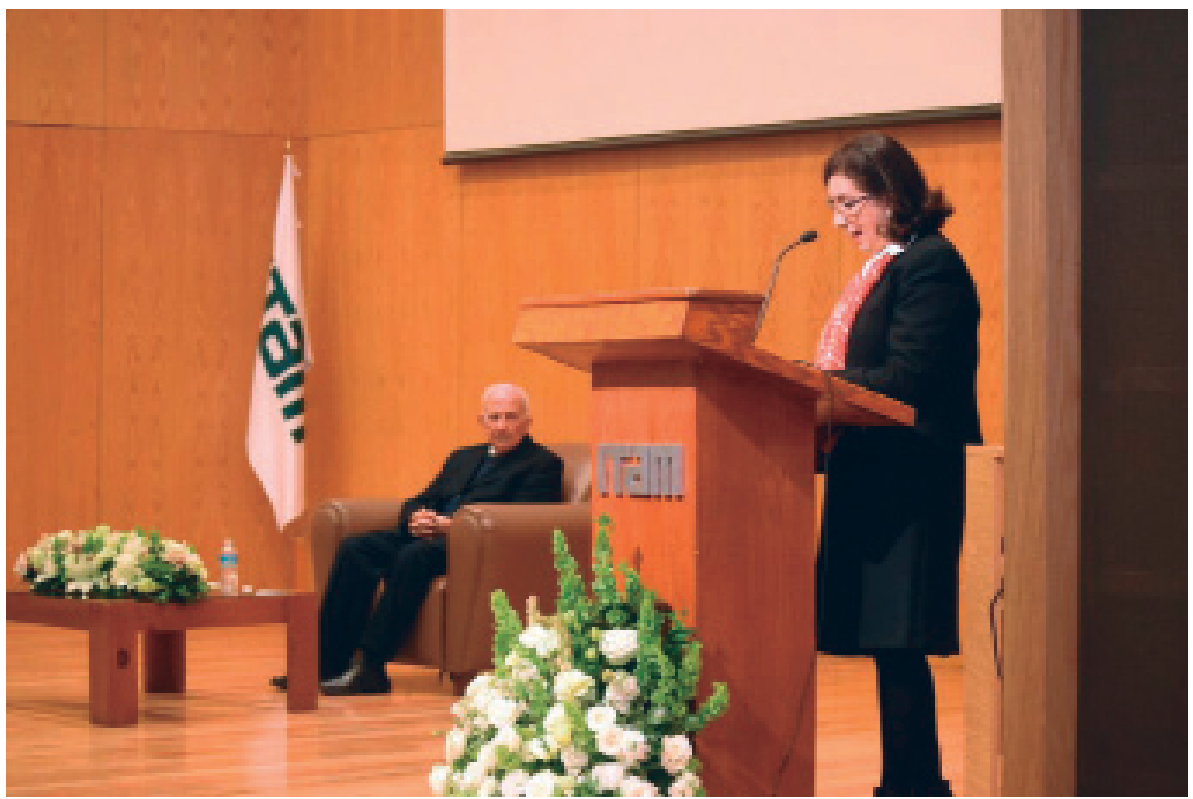

Lydia López, profesora de los Departamentos Académicos de Matemáticas y Estudios Generales.

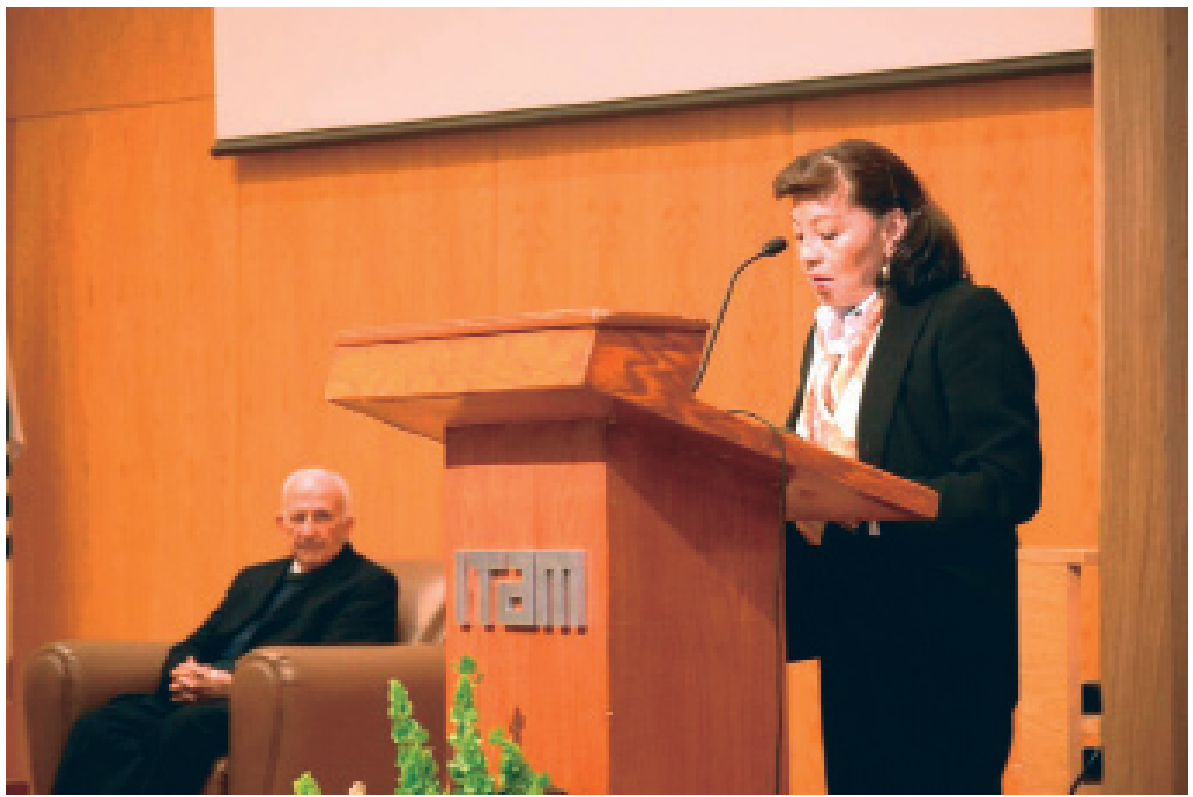

Rosalía Calzada, secretaria de la División Académica de Estudios Generalesy Estudios Internacionales. 


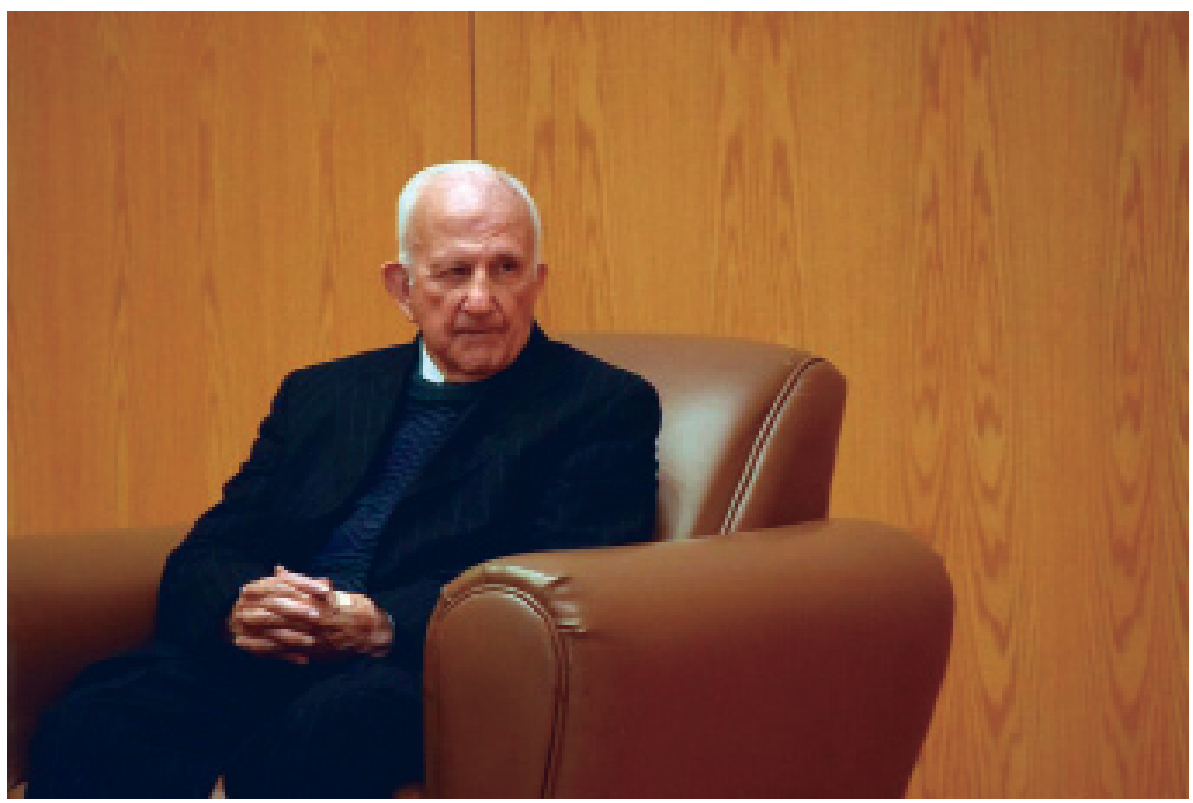

Carlos de la Isla escucha agradecido los discursos en su honor.

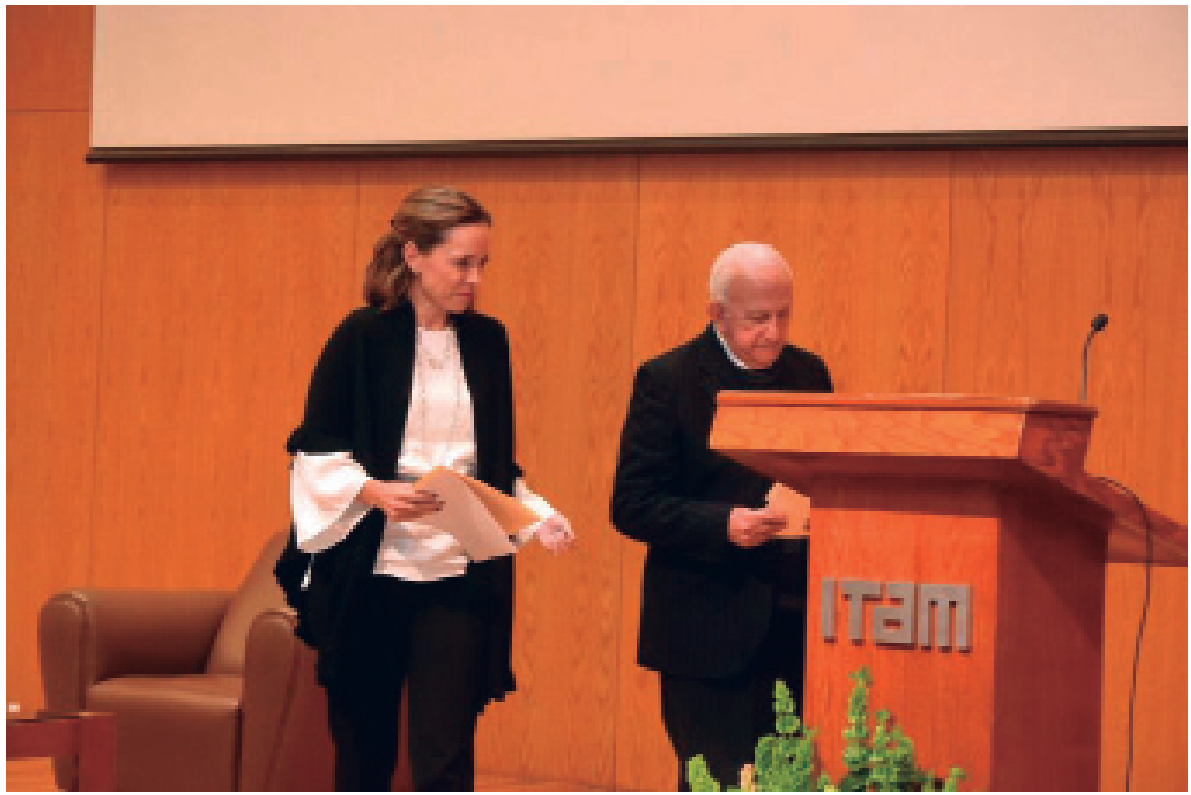

Con Alejandra Peralta, directora de Planeación y Desarrollo. 


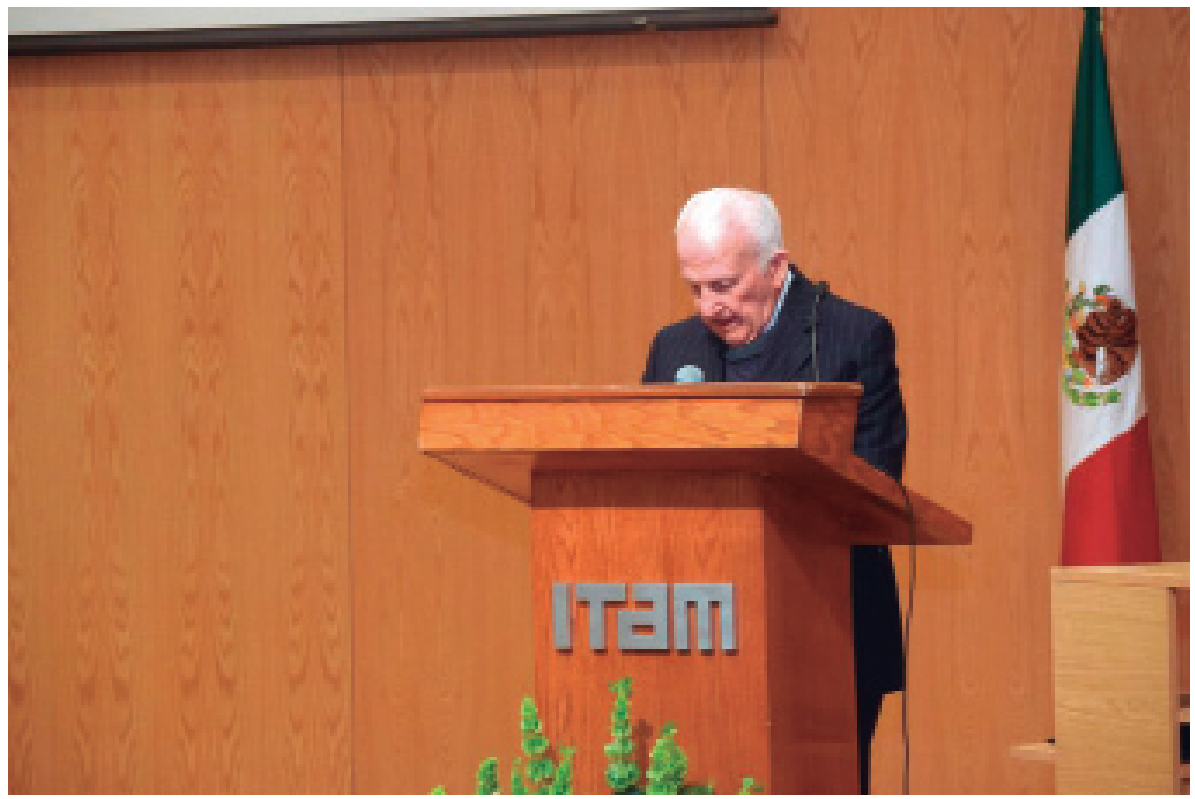

Carlos de la Isla dirige unas palabras de agradecimiento a los presentes.

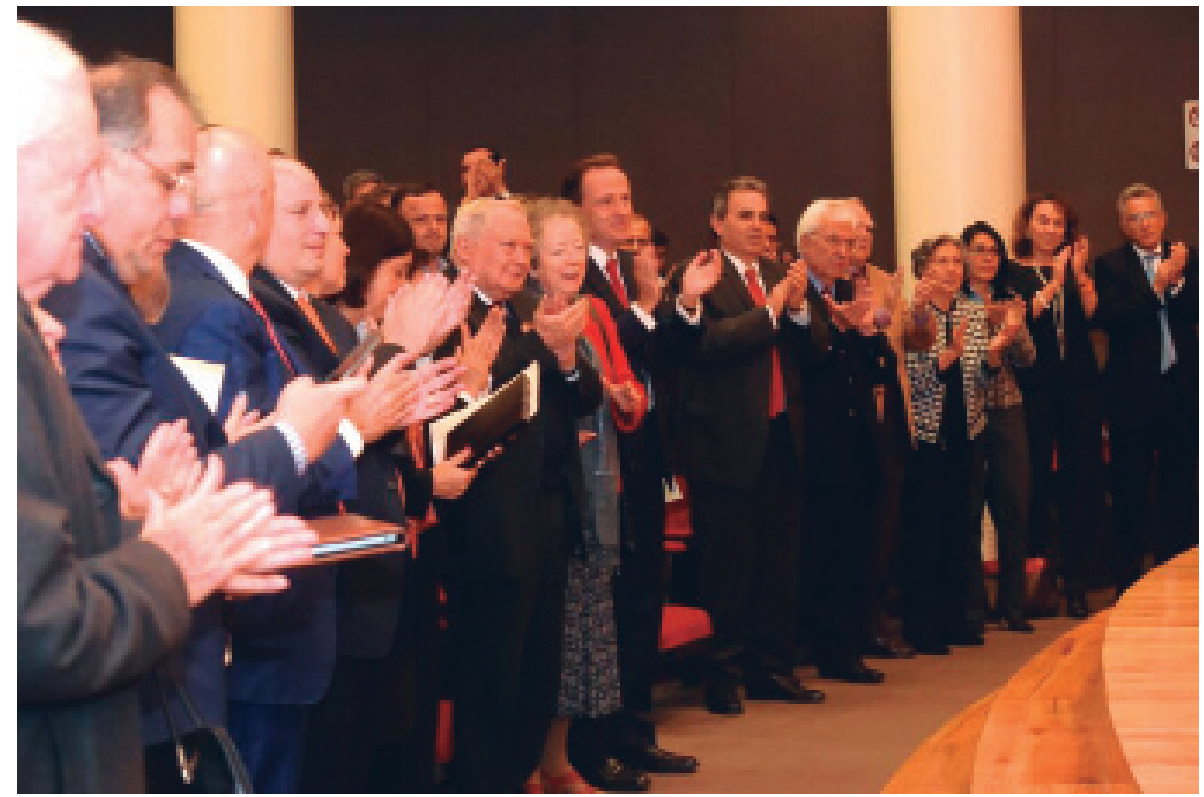

La comunidad del ITAM agradece la inmensa labor de Carlos de la Isla. 


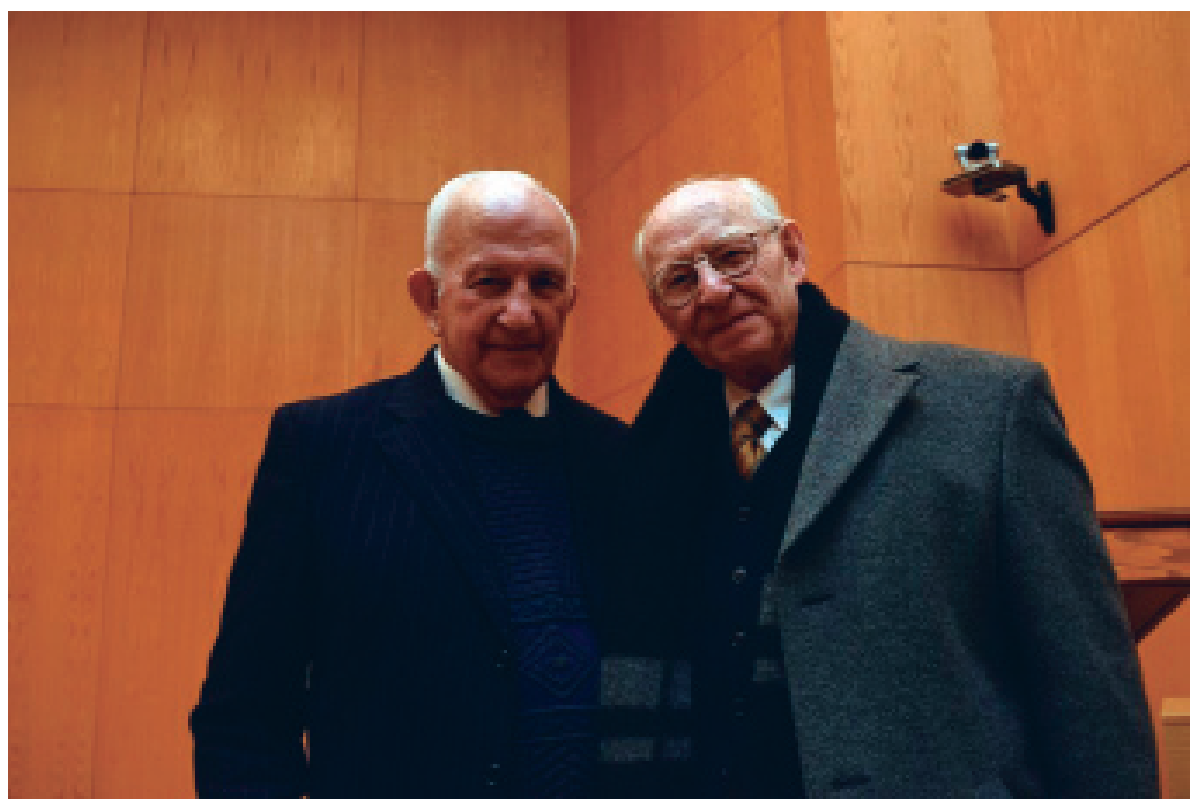

Con José de Jesús Barba Martín, en el Auditorio Raúl Baillères (2016).

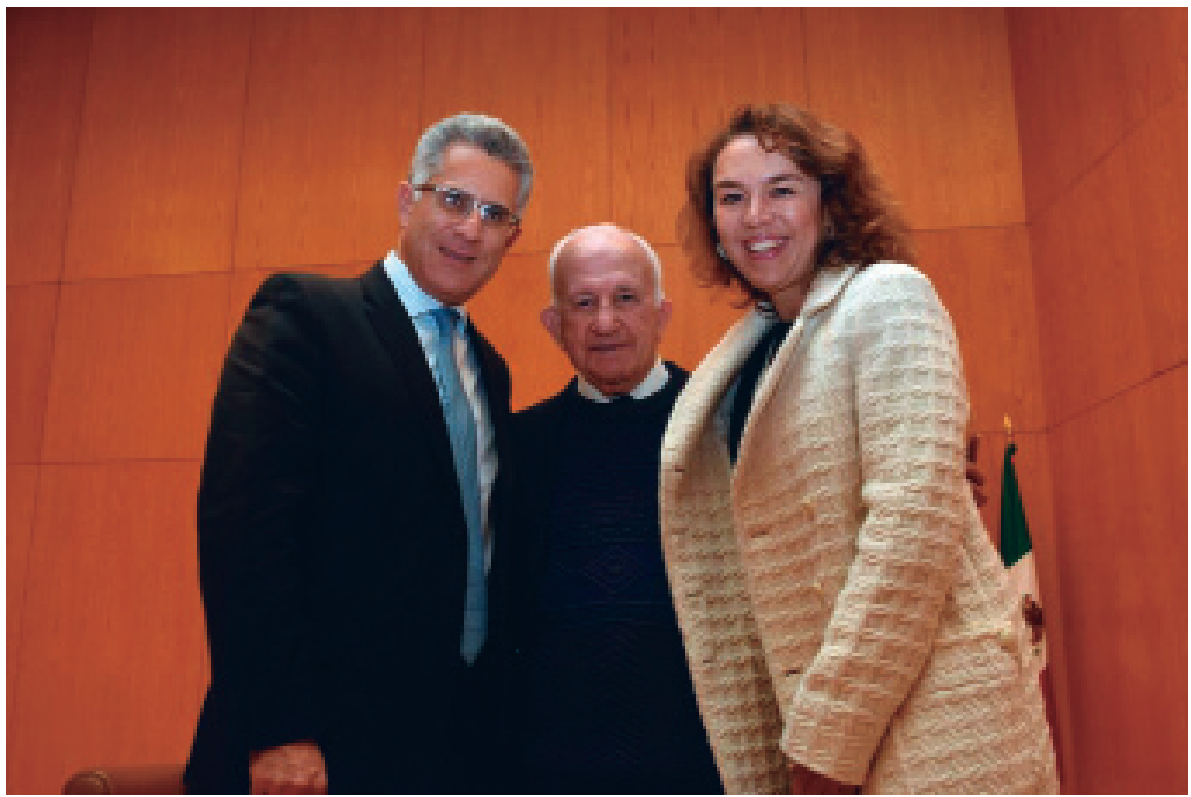

Con el vicerrector Alejandro Hernández y Patricia Medina, directora escolar en el Auditorio Raúl Baillères (2016). 


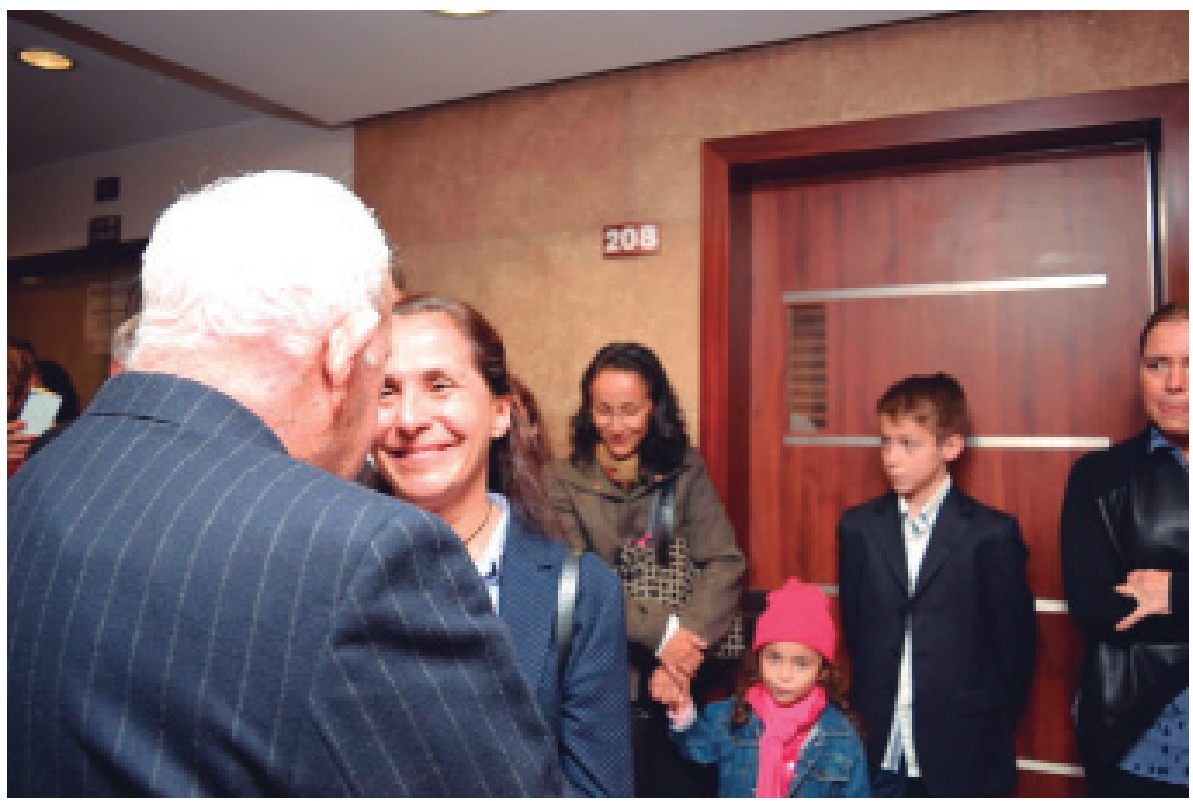

Con Magdalena Barba Fernández, en la instauración del aula "Carlos de la Isla” (2016).

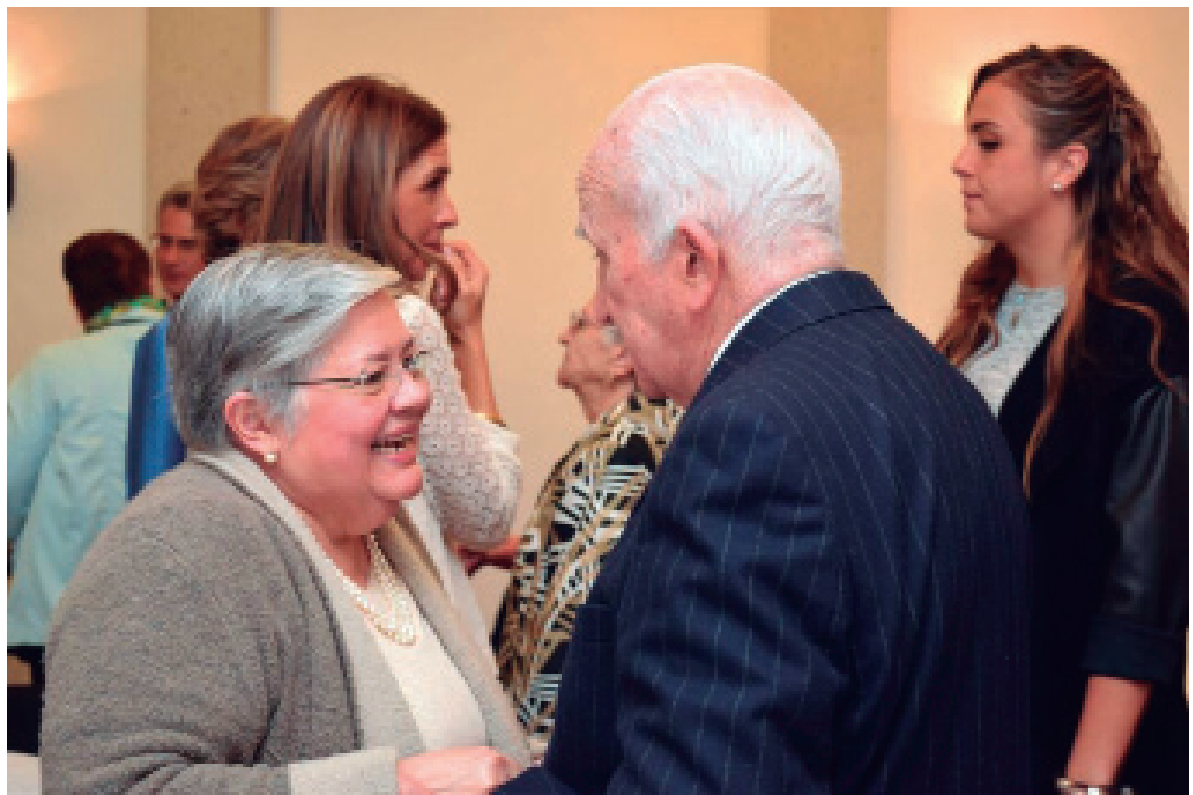

Con María Julia Sierra, en la instauración del aula "Carlos de la Isla" (2016). 


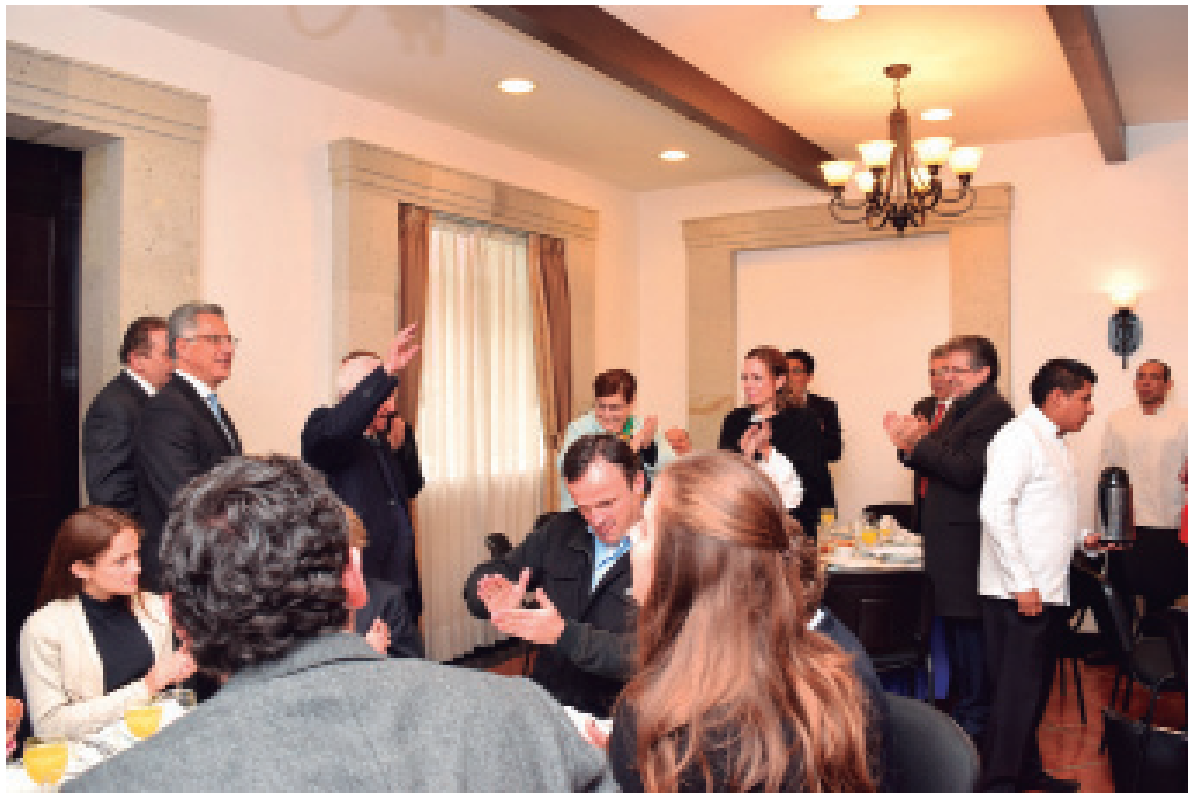

Recibimiento en la Sala de Maestros, después del homenaje (2016).

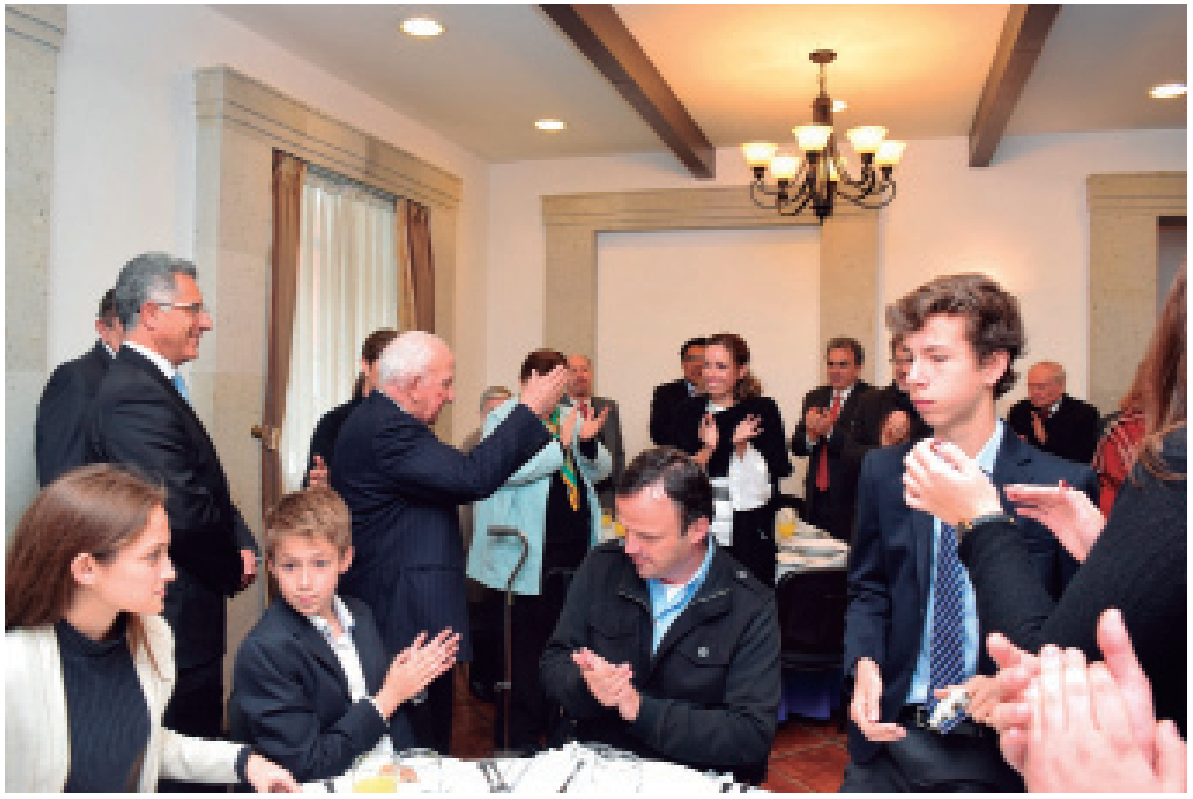

Facultad, familiares y amigos en la Sala de Maestros (2016). 


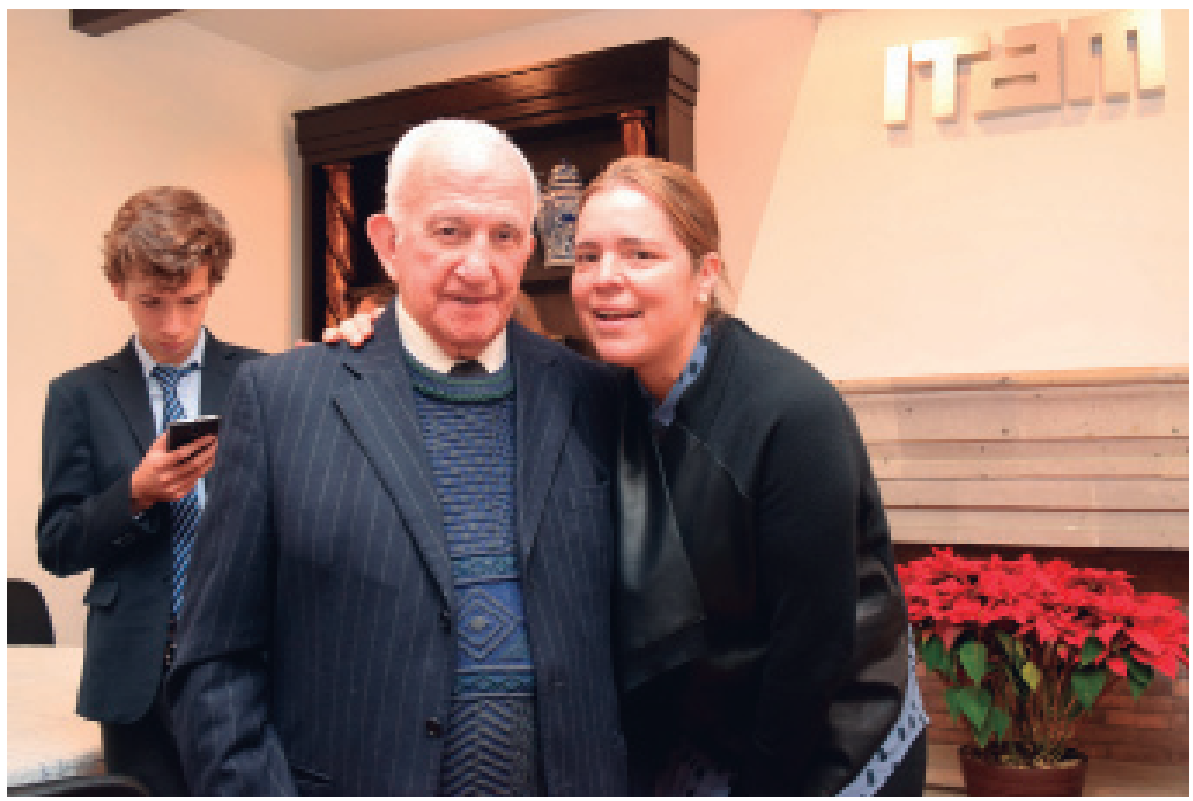

Con Laura Gómez del Campo, jefa de Relaciones Públicas.

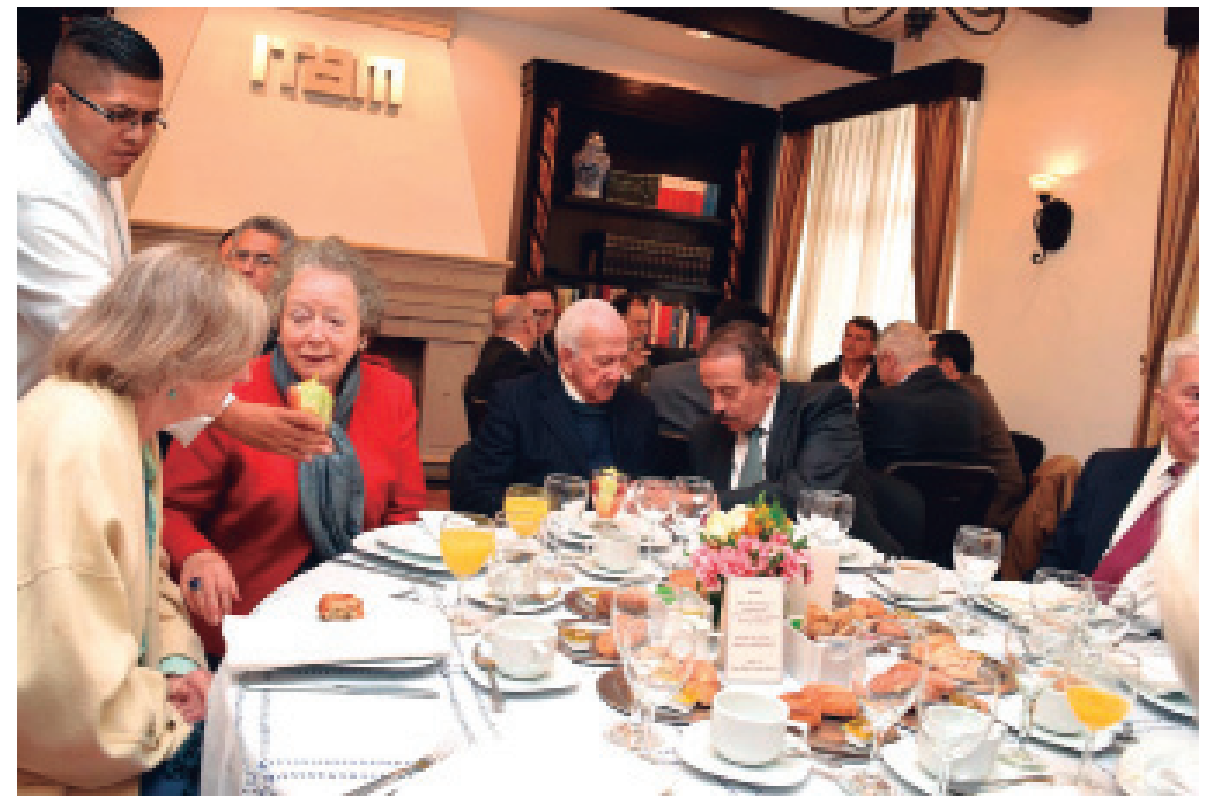

Con su esposa, familiares y amigos. 


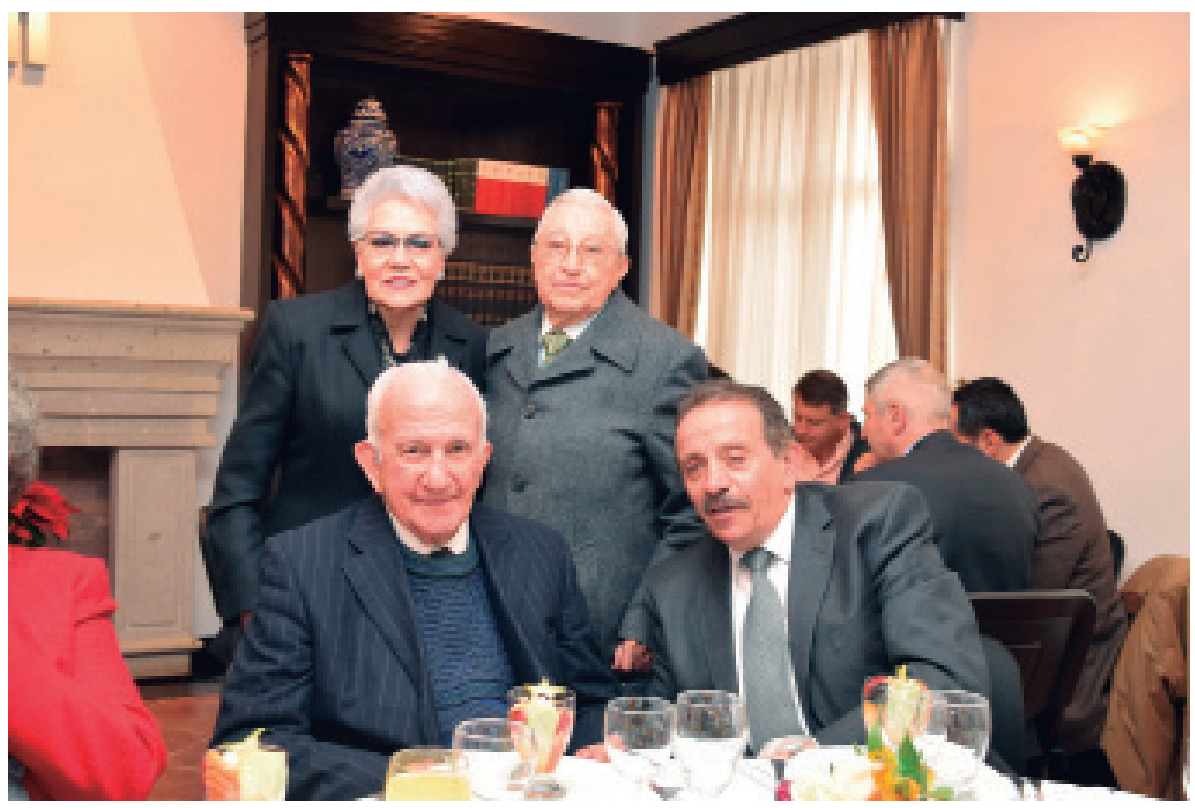

Con sus hermanos y amigos.

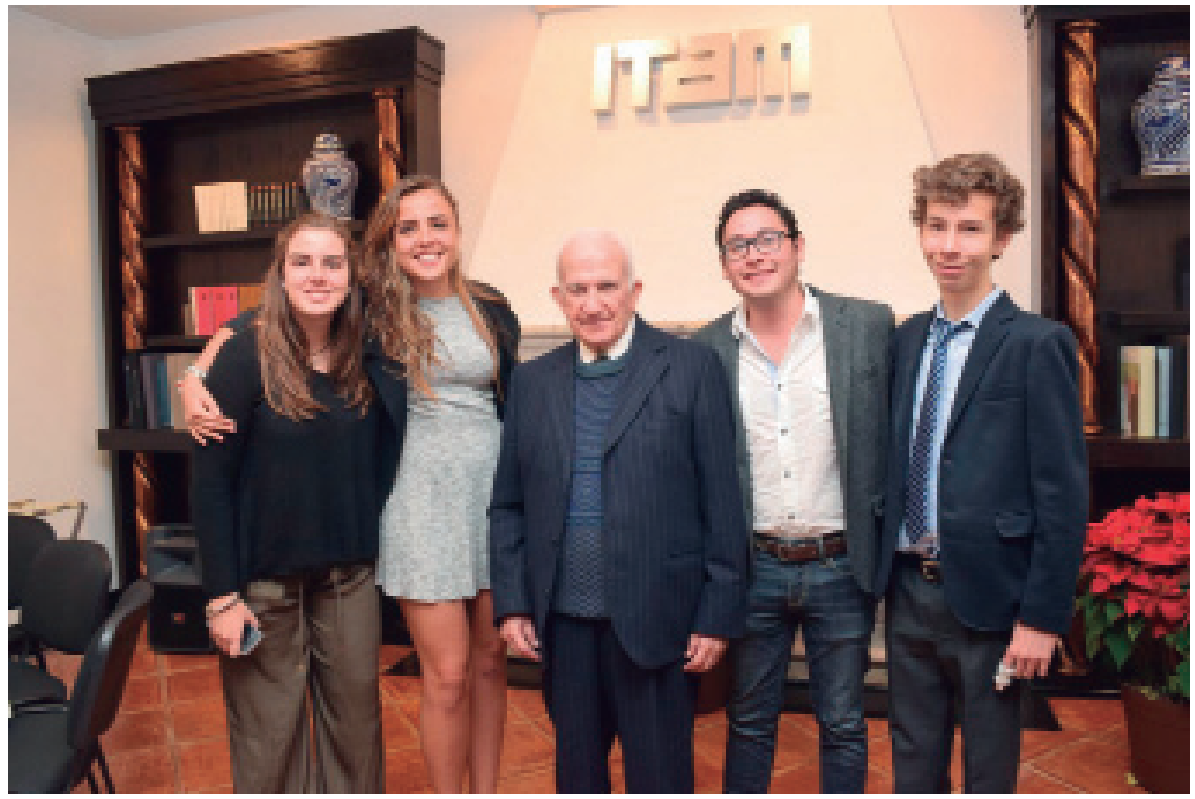

Con sus nietos. 
CITAM Derechos Reservados.

La reproducción total o parcial de este artículo se podrá hacer si el ITAM otorga la autorización previamente por escrito. SECCIÓN FOTOGRÁFICA

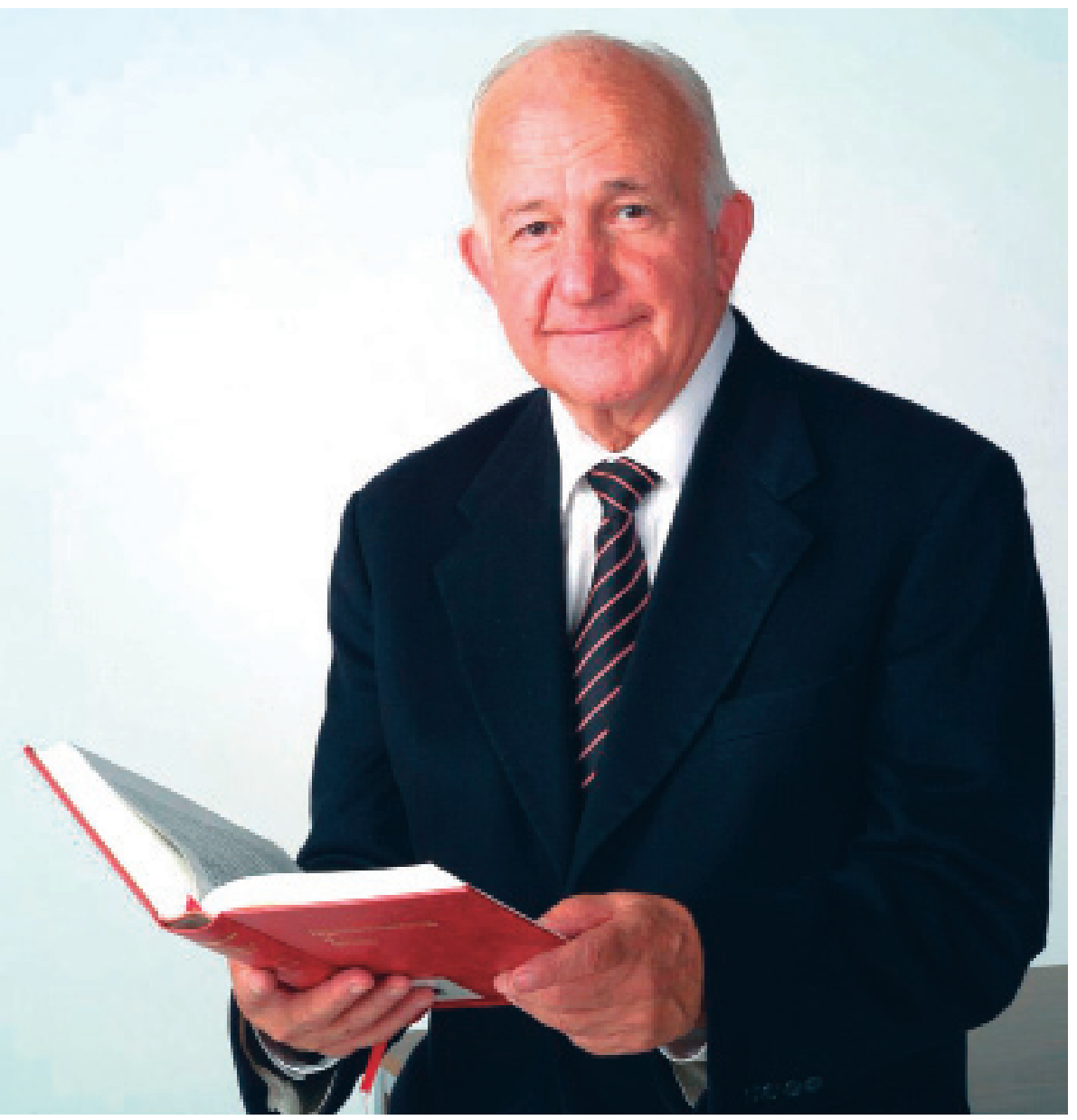

Dr. Carlos de la Isla Veraza

Profesor del ITAM de 1971 a 2016

Profesor emérito desde 1998 Ad multos annos! 